\title{
Pengaruh Pemberian Ekstrak Rimpang Temulawak (Curcuma zanthorrhiza ROXB.) pada Tahap Pascaimplantasi Lanjut terhadap Fertilitas Tikus Putih (Rattus norvegicus L.) betina
}

\section{Effect of Ginger Rhizome Extract (Curcuma zanthorrhiza ROXB.) On Post-implantation Stage against the Fertility of Female White Rats (Rattus norvegicus $\mathbf{L}$.)}

\author{
Erie Fazriany $^{1 *}$, Budhi Akbar ${ }^{1}$, Eka Kartikawati ${ }^{1}$ \\ ${ }^{1}$ Pendidikan Biologi, Universitas Muhammadiyah Prof. Dr. Hamka, Jakarta, Indonesia \\ *Email Korespondensi: efazriany@gmail.com
}

Doi: https://doi.org/10.29405/j.bes/22140-1441337

Received: 28 Mei 2018 | Accepted: 1 November 2018 |Published: 31 Desember 2018

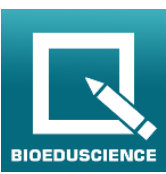

\begin{abstract}
Abstrak
Background: Penelitian ini bertujuan untuk mengetahui adanya pengaruh pemberian ekstrak temulawak (Curcuma zanthorrhiza Roxb.) pada tahap pascaimplantasi lanjut terhadap fertilitas tikus putih (Rattus norvegicus L.) betina galur Sprague Dawley terhadap Kematian Pascaimplantasi (KPI). Metode: Penelitian ini menggunakan Rancangan Acak Lengkap (RAL) yang terdiri dari 4 perlakuan dengan 6 ulangan. Penelitian menggunakan 24 ekor tikus betina yang dibagi dalam empat kelompok yang dibagi menjadi empat perlakuan, yaitu: P0 (kontrol), P1 (400 mg/kg bb), P2 (800 mg/kg bb), P3 (1200 mg/kg bb), perlakuan diberikan setiap hari pada hari ke 11-14 kebuntingan. Pada kebuntingan hari ke-15 tikus dibedah dan diamati jumlah implantasi, fetus hidup, fetus mati dan korpus luteum. Data diuji dengan menggunakan uji Chi kuadrat (X2) dan uji Kruskal Wallis. Hasil: Hasil penelitian menunjukkan perlakuan P1 (400 mg/kg bb) menunjukkan persentase KPI sebesar $0 \%$, perlakuan P2 (800 mg/kg bb) menunjukkan persentase KPI sebesar 5,27\%, dan perlakuan P3 (1200 mg/kg bb) menunjukkan persentase KPI sebesar 14,65\%. Dari hasil yang diperoleh. Kesimpulan: pemberian ekstrak rimpang temulawak pada tahap pascaimplantasi lanjut, cenderung menurunkan fertilitas tikus putih (Rattus norvegicus L.) betina galur Sprague Dawley.
\end{abstract}

Kata kunci: Rimpang Temulawak; Pascaimplantasi; Tikus putih.

Abstract

Background: The aim of this study was to determine the effect of temulawak extract (Curcuma zanthorrhiza Roxb.) On the post-implantation stage on the fertility of female white rats (Rattus norvegicus L.) Sprague Dawley strain on Postimplantation Death (KPI). Method: This study used a Completely Randomized Design (CRD) consisting of 4 treatments with 6 replications. The study used 24 female rats divided into four groups divided into four treatments, namely: P0 (control), P1 (400 mg/kg bw), P2 (800 mg/kg bw), P3 $(1200 \mathrm{mg} / \mathrm{kg} \mathrm{bw})$, treatment is given every day on the 11-14th day of pregnancy. On the 15th day of pregnancy the rats were dissected and observed for the number of implants, the fetus alive, the fetus died and the corpus luteum. Data were tested using the Chi-square test (X2) and the Kruskal Wallis test. Results: The results showed that treatment $P 1(400 \mathrm{mg} / \mathrm{kg} \mathrm{bw})$ showed a percentage of KPI of 0\%, treatment P2 (800 $\mathrm{mg} / \mathrm{kg} \mathrm{bw})$ showed a percentage of KPI of 5.27\%, and treatment P3 (1200 $\mathrm{mg} / \mathrm{kg}$ bw) showed KPI percentage is $14.65 \%$. From the results obtained. Conclusion: administration of curcuma rhizome extract in the post-implantation stage continued, tends to reduce the fertility of white rats (Rattus norvegicus L.) female Sprague Dawley strain.

Keywords: Ginger Rhizome; Post-implementation; White rat.

Cara citasi: Fazriany, E., Akbar, B., dan Kartikawati, E. 2018. Pengaruh Pemberian Ekstrak Rimpang Temulawak (Curcuma zanthorrhiza ROXB.) pada Tahap Pascaimplantasi Lanjut terhadap Fertilitas Tikus Putih (Rattus norvegicus L.) betina. BIOEDUSCIENCE, 2(2): 140-144. Doi: https://doi.org/10.29405/j.bes/22140-1441337 
(C) 2018 Oleh authors. Lisensi Bioeduscience, Uhamka, Jakarta. Artikel ini bersifat open access yang didistribusikan di bawah syarat dan ketentuan Creative Commons Attribution (CC BY) license. (http://creativecommons.org/licenses/by/4.0/).

\section{PENDAHULUAN}

Indonesia merupakan negara agraris dan sebagian besar penduduknya memiliki mata pencaharian di bidang pertanian. Namun, di sisi lain permasalahan serangan hama dilahan pertanian yang dihadapi petani dapat berdampak pada berkurangnya hasil panen (Wahyana, 2015).

Salah satu hama yang sering dikeluhkan oleh para petani padi adalah hama tikus yang menyerang lahan pertanian.

Upaya yang dapat dilakukan untuk pengendalian populasi tikus adalah dengan menggunakan bahan yang bersifat anti fertilitas. Apabila fertilitas tikus dapat ditekan akan berpengaruh pula terhadap populasi tikus (Akbar, 2010). Temulawak (Curcuma zanthorrhiza Roxb.) berpotensi menjadi bahan yang bersifat anti fertillitas karena terdapat kandungankandungan fitokimia seperti alkaloid, flavonoid, saponin, triterpenoid, dan kurkumin. Berdasarkan hasil penelitian lain yang dilakukan oleh Yadav dan Jain (2010 dan 2011), ekstrak aqueous rimpang kunyit (Curcuma longa) yang diberikan pada tikus selama kehamilan hari ke-1 hingga 5 menunjukkan adanya dampak anti fertilitas atau anti implantasi.

Karena kunyit (Curcuma longa) dan temulawak (Curcuma zanthorrhiza Roxb.) memiliki kandungan yang hampir sama yaitu terdapat alkaloid, flavonoid, dan kurkumin. Maka, dapat ditarik persamaan bahwa kedua ekstrak aqueous memiliki potensi sebagai anti fertilitas.

Hipotalamus akan menghasilkan GnRH yang akan merangsang kelenjar hipofisia anterior untuk menghasilkan FSH (Folicle Stimulating Hormone) dan LH (Leuteinizing Hormone). FSH berperan dalam menghasilkan estrogen sedangkan, LH berperan dalam menghasilkan progesteron. Estrogen juga diperlukan dalam hal regulasi progesteron. Kerja progesteron di inisiasi oleh estrogen. Estrogen dan progesteron secara bersama-sama berfungsi dalam memelihara kebuntingan. Hormon lain yang penting adalah hormon luteotropik (LTH) dari kelenjar hipofisa anterior. LTH perlu untuk mempertahankan korpus luteum dan sekresi progesteron (Manan, 2001). Hormon estrogen dan progesteron dapat dihambat dengan pemberian zat yang bersifat estrogenik dari luar tubuh. Hal tersebut dapat dilihat dengan pencekokan ekstrak temulawak yang mengandung senyawa kurkumin, flavonoid dan alkaloid yang bersifat estrogenik (Firdaus, 2015).

Berdasarkan uraian di atas dilakukan penelitian untuk membuktikan pengaruh pemberian ekstrak rimpang Temulawak (Curcuma zanthorrhiza Roxb.) pada tahap pascaimplantasi lanjut memberikan pengaruh terhadap fertilitas tikus putih (Rattus norvegicus L.) betina galur Sprague Dawley.

\section{MATERI DAN METODE}

Proses ekstraksi rimpang temulawak yang digunakan pada penelitian didapatkan dari Balai Penelitian Tanaman Obat dan Aromatik (BALITRO) Bogor. Ekstrak temulawak berupa cairan kental berwarna kuning. Selanjutnya reaksi konsentrasi dilakukan dengan penambahan aquabidestilata.

Penelitian menggunakan rancangan acak lengkap. Sampel dibagi menjadi 4 kelompok, yaitu 1 kelompok kontrol (P0) dan 3 kelompok perlakuan (P1, P2 dan P3). Tiap-tiap kelompok terdiri dari 6 ekor tikus sebagai ulangan. Tikus dipelihara dalam kandang, diberi makan dan minum secara ad libitum. Kelompok kontrol (P0) diberi $0 \mathrm{mg} / \mathrm{kg}$ bb, P1 diberi $400 \mathrm{mg} / \mathrm{kg}$ bb, P2 diberi $800 \mathrm{mg} / \mathrm{kg}$ bb, P3 diberi $1200 \mathrm{mg} / \mathrm{kg}$ bb. Pemberian dilakukan pada pagi hari sebelum diberi makan, sekali sehari selama 4 hari pada usia kebuntingan 11-14 hari secara oral menggunakan jarum sonde lambung. 
Proses pembuatan apusan vagina dilakukan untuk mengecek siklus estrus pada tiap tikus betina. Ambil sedikit cairan $\mathrm{NaCl}$ 0,9\% dengan menggunakan pipet yang berujung tumpul, lalu masukkan ke dalam lubang vagina tikus. Setelah itu semprotkan cairan $\mathrm{NaCl}$ 0,9\% dan hisap kembali teteskan larutan $\mathrm{NaCl} 0,9 \%$ yang sudah dibilas ke dalam vagina tersebut ke permukaan kaca objek lalu keringkan dengan lampu Bunsen. Tetskan cairan metilen blue di atas preparat tersebut dan membilasnya dengan air biasa, lalu dijemur hingga kering. Setelah itu diamati dengan menggunakan mikroskop.

Setelah diamati hasil apusan vagina menunjukkan tikus sedang fase proestrus maka dilakukan pengawinan tikus dengan mencampurkan tikus jantan dengan tikus betina. Pada keesokan hari tepatnya pagi hari pukul 05.30 WIB dilakukan kembali apusan vagina untuk mengetahui ada tidaknya sperma. Apabila terdapat sperma maka diasumsikan sebagai hari pertama kebuntingan.

Pada kebuntingan hari ke-15 tikus dibius dengan kloroform dan selanjutnya dibedah. Pembedahan dilakukan dengan melentangkan tikus di atas papan bedah. Kulit perut yang terletak dekat vulva diangkat dengan pinset lalu digunting. Pembedahan mengikuti arah tanduk uterus tikus yang berbentuk dupleks, yaitu dilanjutkan kearah kiri dan kanan mengikuti garis tanduk uterus. Otot dinding perut dibedah seperti pada pembedahan kulit perut. Kulit ovarium dan uterus yang berisi embrio sudah terlihat, lalu kedua ovarium tikus beserta uterus dilepaskan dengan gunting kecil dan dimasukkan ke dalam larutan $\mathrm{NaCl} \quad 0,9 \%$ secara terpisah. Korpus luteum dilepaskan dari bursa yang membungkus ovarium dengan menggunakan pinset dan gunting. Setelah itu dihitung jumlah implantasi, fetus hidup, fetus mati dan korpus luteum (susilo dan Akbar, 2016).

Data yang telah diperoleh dan hasil perhitungan KPI kemudian diuji normalitasnya dengan menggunakan uji Chi kuadrat $\left(\mathrm{X}^{2}\right)$ dan uji Bartlett untuk mengetahui homogenitas variansi data. Apabila data tersebut menunjukkan data berdistribusi normal dan bervariansi homogen selanjutnya data dianalisis menggunakan Analisis of Variance (ANOVA) lalu dilanjutkan dengan uji BNT untuk mengetahui perbedaan yang nyata antar perlakuan. Apabila data yang diperoleh tidak berdistribusi normal, tidak perlu dilanjutkan uji homogenitas tapi dilanjutkan dengan uji Kruskal Wallis.

\section{HASIL}

Hasil penelitian ditunjukkan pada tabel 1 berikut.

Tabel 1. Persentase rata-rata kematian pascaimplantasi (KPI)

$\begin{array}{cc}\text { Perlakuan } & \text { KPI }(\%) \\ \text { P0 } & 0 \\ \text { P1 } & 0 \\ \text { P2 } & 5,27 \\ \text { P3 } & 14,65\end{array}$

Dari tabel 1 terlihat bahwa persentase kematian pascaimplantasi mengalami peningkatan pada $\mathrm{P} 2(800 \mathrm{mg} / \mathrm{kg}$ bb $)$ dan $\mathrm{P} 3$ $(1200 \mathrm{mg} / \mathrm{kg}$ bb) yaitu $5,27 \%$ dan $14,65 \%$. Sementara P1 (400 mg/kg bb) tidak mengalami peningkatan sama dengan kontrol (P0), yaitu $0 \%$. Berdasarkan uji hipotesis dengan menggunakan uji Kruskal Wallis terhadap parameter KPI menunjukkan $\mathrm{X}_{\text {tabel } 0,95(3)}^{2}=7,81<\mathrm{H}=13,25$ maka, $\mathrm{H}_{1}$ diterima. Dengan demikian dapat disimpulkan bahwa ada perbedaan diantara keempat dosis pencekokan ekstrak rimpang temulawak terhadap persentase kematian pascaimplantasi.

\section{PEMBAHASAN}

Hasil persentase KPI pada tikus yang diberi perlakuan P1 (400 mg/kg bb) pada hari ke 11-14 kehamilan sebesar 0\% terlihat ketika dilakukan pembedahan pada hari ke-15 tidak ditemukannya fetus mati di semua tikus dengan perlakuan P1, hal ini disebabkan karena proses penghambatan FSH (Folicle Stimulating Hormone) dan LH (Luteinizing Hormone) tidak maksimal. Adapun faktor lain yang menyebabkan rendahnya persentase KPI pada perlakuan D1 yakni, FSH 
dan LH hanya bertanggung jawab dalam menjaga kehamilan tikus pada hari ke-1 sampai hari ke-12 sedangkan, pada hari ke-13 sampai melahirkan digantikan dengan hormon LTH (prolaktin) yang merupakan hormon nonsteroid (Nalbandov, 1990). Sehingga pada hari ke-13 dan ke-14 meskipun diberi perlakuan, fetus akan tetap dapat bertahan karena adanya hormon LTH yang dapat mendukung kehidupan fetus. Pada tikus yang diberikan perlakuan P2 (800 mg/kg bb) dan P3 $(1200 \mathrm{mg} / \mathrm{kg}$ bb) ditemukan fetus mati dikarenakan pada dosis tersebut cenderung dapat menghambat sekresi GnRH, dengan terhambatnya sekresi GnRH maka akan menyebabkan terjadinya penghambatan FSH dan LH pada hari ke-11 dan 12 kehamilan, sehingga pada saat itu estrogen dan progesteron terhambat. Sehingga, fetus akan mengalami kematian yang disebabkan terhambatnya suplai nutrisi untuk fetus yang berasal dari pembuluh darah endometrium akibat rendahnya kedua hormon tersebut (Dzulfiqor et al, 2015). Plasenta mampu menghasilkan hormon estrogen dan progesteron lebih besar dari yang dihasilkan korpus luteum, dikarenakan adanya peran hormon Chorionic Gonadotrofin, yang memiliki kemiripan dengan hormon LH, yang dapat pula merangsang plasenta untuk menghasilkan estrogen dan progesteron. Plasenta menghasilkan hormon estrogen, dengan mengubah hormon androgen yang diproduksi oleh janin, dehidroepiandrosteron (DHEA) menjadi estrogen. Plasenta mengekstraksi DHEA dari darah janin dan mengubahnya menjadi estrogen. Estrogen primer yang disintesis dengan cara ini adalah estriol, berbeda dari estrogen utama yang diproduksi oleh ovarium yaitu estradiol. Estriol, yang tidak diproduksi oleh ovarium akan diproduksi dalam kadar tinggi pada kehamilan. Sehingga dengan tetap dihasilkannya estrogen dan progesteron oleh plasenta dapat menjaga kelangsungan hidup fetus selama kehamilan, meskipun FSH dan LH pada ovarium dihambat (Heffner, 2005; Sherwood, 2011 dan Vander et al., 2001).

\section{KESIMPULAN}

Berdasarkan hasil penelitian pengaruh pemberian ekstrak rimpang temulawak (Curcuma zanthorrhiza Roxb.) pada tahap pascaimplantasi cenderung mempengaruhi fertilitas tikus putih (Rattus norvegicus L.) betina galur Sprague Dawley. Dosis 1200 mg/kg bb cenderung menaikkan kematian pascaimplantasi pada tahap lanjut.

\section{REFERENSI}

Akbar, B. 2010. Tumbuhan Dengan Kandungan Senyawa Aktif Yang Berpotensi Sebagai Bahan Anti fertilitas. Jakarta: Adabia Press.

Dzulfiqor, Y., Akbar, B., dan Susilo. 2015. Uji Ekstrak Etanol Daun Pegagan (Centella asiatica L. Urban) terhadap Fertilitas Tikus Putih (Rattus norvegicus L.) Betina pada Tahap Praimplantasi. Al-Kauniyah Jurnal Biologi. 8(2): 101-106.

Firdaus, H. 2015. Pengaruh Pemberian Ekstrak Temulawak (Curcuma xanthorriza, R.) dan Brotowali (Tinospora crispa, L.) Terhadap Uterus Tikus Putih (Rattus norvegicus, L.). Jogjakarta: UNY

Heffner dan Schust. 2005. At a Glance Sistem Reproduksi Edisi Kedua. Jakarta: Erlangga

Manan, D. 2001. Ilmu Kebidanan Pada Ternak. Aceh: Universitas Syiah Kuala Darussalam

Nalbandov, A.V. 1990. Fisiologi Reproduksi Pada mamalia dan Unggas (Penerjemah Keman, S.). Jakarta: UI Press

Sherwood, L. 2011. Fisiologi Manusia: Dari Sel ke Sistem. Alih bahasa, Brahm U. Jakarta: ECG.

Susilo dan Akbar, B. 2016. Pengaruh Ekstrak Buah Takokak (Solanum torvum S.) Terhadap Jumlah dan Motilitas Spermatozoa Tikus Putih (Rattus norvegicus L.) Galur Sprague Dawley. BIOMEDIKA. 9(2): 45-51

Vander, A., Sherman, J. dan Luciano, D. 2001. Human Physiology The Mechanisms of Body Function. New York: The Mc Graw-Hill Companies, Inc

Wahyana, A. 2015. Pengendalian Hama Tikus Terpadu. Subang: Balai Besar Penelitian Tanaman Padi

Yadav, R. dan Jain, G.C. 2010. Post-Coital Contraceptive Efficacy of Aqueous Extract Of Curcuma longa Rhizome In Female Albino Rats. India: Pharmacology online

Yadav, R. dan Jain, G.C. 2011. Effect of Contragestative Dose of Aqueous Extract of 
Curcuma longa Rhizome on Uterine Biochemical Milieu of Female Rats. India: Indian Journal of Fundamental and Applied Life Science. 